EwELINA SILECKA-MAREK

ORCID 0000-0003-3710-0470

Uniwersytet im. Adama Mickiewicza

$w$ Poznaniu

\title{
THE CHARACTERISTICS OF COURT PROBATION SERVICE FOR ADULTS IN POLAND
}

Aвstract. Silecka-Marek Ewelina, The Characteristics of Court Probation Service for Adults in Poland [Funkcjonowanie kuratorskiej służby sądowej dla dorosłych w Polsce]. Studia Edukacyjne nr 52, 2019, Poznań 2019, pp. 257-271. Adam Mickiewicz University Press. ISSN 1233-6688. DOI: 10.14746/ se.2019.52.17

For many years, there has been a tendency in Poland to organize preventive and rehabilitation activities for offenders as much as possible in environment of freedom. This results, among other things, from criticizing the penalty of deprivation of liberty, which does not fully implement the goals set for it, disappointing with its results and thus searching for more effective ways of transforming, modifying or modeling the attitudes and behaviors of socially maladjusted people. The probation officer is an important instrument of social control and social rehabilitation impact on both minors and adults. He faces new challenges resulting from socio-economic changes, and in the changing social reality, the behavior of defendants also changes. This requires the probation officer to be mindful, flexible, and respond quickly to the rehabilitation needs of supervised.

Key words: Family probation officer, Adult probation officer, rehabilitation, probation

For many years now, there has been a tendency in Poland to organise prevention and resocialization activities for perpetrators of punishable and prohibited acts in a free environment whenever possible. The reasons for that include, among others, constant criticism of imprisonment that does not entirely fulfil its objectives (art. $67 \S 1$ of $\mathrm{kkw}^{1}$ ), dissatisfaction with its results and thus search for more effective ways of transforming, modifying or modelling the attitudes and behaviours of people who are socially maladjusted. One cannot ignore the transformations in the widely understood system of probation, especially

${ }^{1}$ Act of 6 June 1997 - Kodeks karny wykonawczy (Executive penal code) (Journal of Law 2018.0.652), kkw for short. 
within the Polish court probation, that provide prospects for the completion of the educational function of a punishment. One also has to take into account the effective functioning of court probation officers themselves, because the efficiency of many changes in the penal law or proceedings towards the juvenile depends on the activities that they take up. The expectations towards this professional group as far as the process of defendant resocialization is concerned are linked to an increasing number of tasks imposed on it, which, in turn, affects its effectiveness and psychophysical condition.

The profession of a probation officer is an extraordinarily stressful one. In the light of research results by Bartłomiej Skowroński, one can observe that their specialization, i.e. juvenile custody vs. adult custody, diversifies the subject group only in relation to the evaluation of stressors linked to variance and ambiguity, carrying out job duties, control activities and insufficient physical work conditions. In both cases, probation officers executing adjudications in penal cases showed a significantly higher level of stress and they perceived their duties as unclear. Both professions differ as far as the type of tasks performed and client characteristics are concerned (children vs. adults). It might seem that family probation officers experience more emotional exploitation, for instance due to the types of cases they manage, such as taking a child away from parental authority, placing a child in an educational care facility etc. It turned out, however, that stress accompanies both specializations to the same degree. ${ }^{2}$ Probation officers operate in the environment of those under their custody, as well as in closed facilities and institutions where those under they custody stay, in particular prisons, educational care facilities and treatment-rehabilitation facilities. ${ }^{3}$ In their everyday work, probation officers enter relations with socially maladjusted individuals, play the role of an advisor, mediator and sometimes controller, and participate in solving difficult conflict situations. Their decisions frequently influence further functioning of the individual or family. Their knowledge, skills, competences and intuition (often resulting from life and professional experience) are of great importance, as well as their effective organization and coordination of educational activities. The personality model of a probation officer should be built around a specific self-concept and world concept: teaching talent, self-criticism, firmness, kindness and easiness to build interpersonal relations, personal authority and humanistic attitude towards others. ${ }^{4}$ Due to the number of emotionally

${ }^{2}$ B. Skowroński, Stres sądowych kuratorów zawodowych wykonujacych orzeczenia w sprawach karnych i nieletnich, Resocjalizacja Polska, 2015, 10, p. 223.

${ }^{3}$ Act of 27 July 2001 on court probation officers (Journal of Law 2018, item 1400), u.o.k.p. for short, art. 3 section 1 .

${ }^{4}$ Text published on 19 March 2006 at www.kurator.org.pl [accessed on: 15.04.2018] Defendants are sharp observers, which is why the external features of a probation officer, i.e. appe- 
charged cases that they have to deal with, the need to supervise probation officers is pointed to. Often, a team meeting and joint analysis of the course of work with a person under custody would suffice in order to discuss successes and errors in interactions, and modify them if necessary. The research results on the occurrence of stress among court probation officers by $€$. Wirkus indicate that a system of prevention could be built that would make it possible to create conditions for cooperation when solving difficult situations and design a base for developing professional competences. This could contribute to a decrease in the health toll experienced by the professional group discussed and in the risk of professional burn-out. ${ }^{5}$

The $\operatorname{act}^{6}$ passed in 2001 defined, however, the formal requirements a candidate for a professional probation officer faces. They are expected to have specialist education in pedagogical and psychological, sociological or legal science, or any other education and postgraduate studies in the specializations listed above, impeccable character, appropriate physical and mental health, legal training for probation officers and exam for probation officers passed. The increased qualification criteria are supposed to guarantee that candidates recruited for this profession are well-educated and well-prepared to work under difficult conditions.

A court probation officer is a public officer ${ }^{7}$ who carries out tasks of educational, resocialization, diagnostic, preventive and control character linked to the execution of court adjudications as defined by law. ${ }^{8}$ The scope of a probation officer's tasks is incredibly wide, and broadened even further by changes in the law (Table 1). It is the duty of probation officers to execute and supervise practically all the sanctions and measures that are an alternative to isolation and placement away from the family environment of those under their custody. In other European countries or in the United States, not only is a similar scope of tasks carried out by a considerably more numerous staff, but it is also handled by many different services. ${ }^{9}$

arance, looks, age and even clothes, are also important when one enters a relation with them. Defendants often have low self-esteem and react badly to others displaying signs of their higher social position. It is important to relieve their anger and insecurity, and introduce them to an atmosphere of hope, kindness, perception of their own possibilities, acceptance and trust, i.e. work on resources instead of deficitp.

${ }^{5}$ K. Nanowska (book review) of Ł. Wirkus's, Stres w pracy kuratora sadowego. Studium teoretyczno-empiryczne, Edukacja Humanistyczna, 2016, 2, p. 185.

${ }^{6}$ U.o.k.p., ibidem.

7 Ustawa z 6 czerwca 1997 r. - Kodeks karny (DzU 2018, poz. 1600), art. 115 § 13 point 3 of k.k (Act of 6 June 1997 - Penal Code (Journal of Law 2018, 1600), kk for short.

8 Art. 1 of u.o.k.p.

90 lat kurateli sądowej w Polsce, Historia - Teraźniejszość - Przyszłość, Warszawa 2010, p. 19. 
Tasks of court probation officers

\begin{tabular}{|c|c|c|c|}
\hline \multicolumn{2}{|c|}{ Family probation officers } & \multicolumn{2}{|c|}{ Adult probation officers } \\
\hline $\begin{array}{c}\text { Court } \\
\text { proceedings }\end{array}$ & $\begin{array}{l}\text { Executive } \\
\text { proceedings }\end{array}$ & $\begin{array}{l}\text { Preparation } \\
\text { proceedings }\end{array}$ & $\begin{array}{l}\text { Executive } \\
\text { proceedings }\end{array}$ \\
\hline $\begin{array}{l}\text { - community in- } \\
\text { terviews } \\
\text { - temporary su- } \\
\text { pervision }\end{array}$ & $\begin{array}{l}\text { - community in- } \\
\text { terviews } \\
\text { - supervision } \\
\text { - control tasks } \\
\text { - participation in } \\
\text { parents' contacts } \\
\text { with children } \\
\text { - collecting an } \\
\text { individual under } \\
\text { parental authority } \\
\text { - participation in } \\
\text { meetings of an } \\
\text { interdisciplinary } \\
\text { team } \\
\text { - other tasks }\end{array}$ & $\begin{array}{l}\text { - community in- } \\
\text { terviews }\end{array}$ & $\begin{array}{l}\text { - supervision } \\
\text { - electronic su- } \\
\text { pervision } \\
\text { - non-custodial } \\
\text { sentence } \\
\text { - providing aid } \\
\text { from FPPiP10 } \\
\text { - duty control } \\
\text { without supervi- } \\
\text { sion } \\
\text { - participation in } \\
\text { meetings of an } \\
\text { interdisciplinary } \\
\text { team }\end{array}$ \\
\hline
\end{tabular}

Source: A. Brudnoch, cooperation: B. Grabowska-Moroz, Status zawodowych kuratorów sądowych w polskim wymiarze sprawiedliwości, Analizy i Rekomendacje, 2016, 3, Helsińska Fundacja Praw Człowieka, p. 5.

Work standards for professional probation officers were regulated in the order by the Minister of Justice ${ }^{11}$ according to which a probation officer who executes sentences in family and juvenile cases manages up to 100 cases, including 50 cases of their own, whereas a probation officer who executes sentences in penal cases manages up to 120 cases, including 50 cases of their own. In $\S 2$ of the order, it is indicated that the standards of work burden for professional probation officers do not define holding community interviews and presence in parents' contacts with children as set by custody courts.

When carrying out the above duties with a defendant, the probation officer has the right to visit them where they live or stay (between 7 a.m. and 10 p.m.) and in closed facilities, request the defendant to show an ID to confirm their identity, request necessary explanations and information from the person under supervision, surveillance or other form of control adjudicated by the court, review court records and make copies of them as part of them

101 Fundusz Pomocy Pokrzywdzonym i Pomocy Postpenitencjarnej - Fundusz Sprawiedliwości (Victim Support and Post-Penitentiary Aid Fund - Justice Fund, FPPiP for short).

${ }_{11}$ Order of the Minister of Justice of 9 June 2003 on standards of work burden for professional probation officers (Journal of Law 2003 No 116, item 1100). 
carrying out their official duties, and access documentation related to the person under their custody and other people in the proceedings, as well as request the Police and other authorities or public institutions, local government authorities, associations and social organizations within their scope of operations, as well as individuals, to help them carry out their official duties. ${ }^{12}$ The Council of Europe's guidelines also recommend engaging representatives of the society in executing alternative measures and sanctions. Among others, the Council recommends defining criteria and procedures for selecting private individuals to carry out the tasks, managing their work by professional staff that would be responsible for supervising and training them at the same time, insuring those individuals against accidents, injuries and civil liability and reimbursing them with the necessary expenses related to their work. According to the act on court probation officers, a social probation officer has to have the same qualifications as a professional probation officer (citizenship, full civil and citizen rights, flawless character and very good health), as well as at least secondary education, experience in resocialization work and certificate of clean criminal record (art. 84 section 1 of u. o k.s.). A professional probation officer who cooperates with a social probation officer is obliged to organize and control their work and train them (art. 11 point 4 of u. o k.s.).

The study on court probation service prepared by the Helsinki Foundation for Human Rights in 2016 says that

effective functioning of this professional group is of the utmost importance as the effectiveness of a number of legal changes in penal law or proceedings towards the juvenile depends on how court probation officers operate. On the one hand, the tasks performed by probation officers lead to crucial consequences in the sphere of the rights and duties of an individual. On the other hand, a probation officer's task is to help the condemned to readapt socially and the juvenile to resocialize, motivate and support parents in their custody and bringing up of their children, protect the interests of the underage and work for decreasing social pathology. In this sense, probation officers' activities translate into the level of order and security of the citizens. ${ }^{13}$

\section{Court probation service in Poland in figures}

At the end of 2016, court probation service had a staff limit of 5,211.50 professional probation officers. There were $21.5 \%$ male probation officers. The average age of professional probation officers was 49; the youngest one was 25 and the oldest one was 72. Among over 5,000 people, nearly 97\% had higher edu-

${ }^{12}$ Art. 9 of u.o.k.p.

13 A. Brudnoch (cooperation: B. Grabowska-Moroz), Status zawodowych kuratorów sądowych w polskim wymiarze sprawiedliwości, Analizy i Rekomendacje, 2016, 3, Helsińska Fundacja Praw Człowieka, p. 2. 
cation, and 28 individuals (0.5\%) had a PhD title. Over 3,000 individuals graduated from pedagogical studies, including resocialization (912 individuals), which is the dominant field of study among those indicated by the lawmaker. One can also observe that probation officers increase their competences by, for example, supplementing their education with postgraduate studies.

According to the Act on court probation officers (art. 7), there are three levels of professional promotion: professional probation officer, senior professional probation officer, specialist professional probation officer. At the end of 2016, the most numerous group was that of specialist probation officers $(60.5 \%)$, which is linked not only to their many years of work and experience gathered, but also to the need to be engaged in their work in order to be promoted on this basis. $23 \%$ of the population at that time were senior probation officers, whereas $14.9 \%$ were professional probation officers. Based on monitoring figures gathered along the years, one can observe that an average of about $5 \%$ probation officers are promoted every year. There are, however, disproportions among districts; for example, most specialist probation officers i.e. $91.3 \%$ work in the Torun district, whereas the smallest number of them i.e. $29.7 \%$ work in the Katowice district. These differences cannot be evaluated only based on one's engagement in work, because the picture is influenced by a range of factors, among others the so-called promotion and human resources needs, and organizational issues.

The situation of social probation officers is interesting. On 31 December 2016 , court probation services were comprised of 24,971 social probation officers, of which 12,844 social probation officers dealt with adult custody and 12,087 social probation officers dealt with family custody. As compared with 2014 , the number of social probation officers decreased by 2,862 persons. There were 2,511 fewer probation officers in the penal department and 351 fewer probation officers in the family department.

With the general declining tendency, a relatively large group of social probation officers is still appointed to serve. The movement in this area is thus two-directional. In 2016, 2,537 social probation officers were dismissed, and at the same time that year 1,249 new social probation officers were appointed. The main reasons to dismiss social probation officers included: the natural process of generational exchange and random incidents (in case of 1,245 probation officers), decreased work burden (921 probation officers), low level of work (177 probation officers), low level of flat rates (142 probation officers) and loss of trust (56 social probation officers). They are replaced with new people who are better-educated, and prepared for resocialization work and the required level of reporting. This process proves that professional probation officers pay due care to the level of tasks carried out. ${ }^{14}$

${ }^{14}$ Kuratorska Służba Sądowa w Polsce wg stanu na dzień 31.12.2016 roku. Opracowanie Komisji ds Monitorowania Warunków Pracy, Płac i Obciążeń Obowiązkami Kuratorów Krajowej Rady Kuratorów Sądowych, Warszawa 2017, p. 19-20. 
It seems that human resources movements in the area of social probation are a consequence of the long process of reforming probation service in Poland. They also originate in the so-called professionalization of probation that assumes great care as far as the adequate level of tasks performed by probation officers is concerned and specialized education that increases this guarantee as required by the act on probation officers. In my opinion, the thesis that a given kind of education influences (if at all) the effectiveness of resocialization interventions taken up is highly general and disputable. Apart from education, the act on probation officers (art. 5 section 1 - on professional probation officers; art. 84 - on social probation officers) indicates other qualifications required from the candidates who apply to become a court probation officer, such as the above-mentioned Polish citizenship and full civil and citizen rights, very good health, flawless character. However, education is the elementary category that differentiates a social probation officer from a professional probation officer.

These requirements are almost identical with those defined for candidates who apply to become a district court judge. K. Gromek pointed out that there is an aspiration to define standards on the top level and unify standards set to employees of the judiciary who fulfil particularly important social functions. ${ }^{15}$ The requirement for probation officers to be of flawless character is questioned, as attempts have been already made to specify this term with reference to judges, but to no avail. It is a term that refers to behaviour which is not regulated by penal law, it touches upon a candidate's moral sphere and some preferable traits that they should be described with, such as: honest, hard-working, unimpeachable, even-tempered, diligent, brave, patient, kind, self-critical, intellectually open, sensitive, well-mannered. ${ }^{16}$ Interestingly, when appointing one as a social probation officer, these traits are impossible to verify. They are impossible to verify at the first stage of appointing one as a professional probation officer, either. Only a probation application may serve as the time to observe the candidate's behaviour.

At the end of 2016, the number of social probation officers was the lowest in 13 years, and reached the number of social probation officers from 2002. The decrease in the number of social probation officers occured mainly in the penal department, which was linked not only to the requirements described above, but also to a large decrease in cases of the supervised. One can predict that the declining tendency will also be noticed in the upcoming years and cases of the supervised will be handled mainly by professional probation officers.

${ }^{15}$ K. Gromek, Kuratorzy sadowi. Komentarz do ustawy z 27 lipca 2001, Warszawa 2002, p. 62.

${ }_{16}$ T. Ereciński, J. Gudowski, J. Iwulski, Komentarz do prawa o ustroju sądów powszechnych i ustawy o Krajowej Radzie Sądownictwa, Warszawa 2002, p. 167. 
In the year 2016 that is discussed here, probation officers for adults carried out decisions in 311,743 cases, whereas in the same period in 2014 there were 380,045 cases, which means a decrease by 68,302 cases (18\%). On average, one probation officer had 101.8 cases in 2016 and 123.1 cases in the same period in 2014. The average burden thus decreased by 21.3 cases $(17.3 \%)$. These figures cannot, however, be proportionally translated into a decreased amount of work or activities taken up by probation officers. One has to remember that each case refers to a different individual or family whose level of dysfunction and problems to solve may be extremely disparate and linked to devoting considerably more time by the probation officer, as well as involve the help or cooperation of other people and specialists. What is more, the number of tasks a probation officer has to deal with depends on the qualification of their defendants to the so-called risk group, which means that some cases are easy and others are difficult and much more absorbing.

The average supervision burden in 2016 was similar to the cases handled by probation officers for adults. There were 151,287 own and entrusted supervisions, and 212,941 in the same period in 2014. This means a decrease in the overall number of supervisions by $61,654(29 \%)$. On average, one professional probation officer for adults had 49.4 supervisions in 2016, and 69.0 supervisions in the same period in 2014 . The average burden thus decreased by 19.6 supervisions $(28.4 \%)$.

In 2014-2016, the decrease of 19.6 cases in the average number of all supervisions for one probation officer led to the decrease of 5.8 in the average number of own supervisions and of 13.8 in the average number of entrusted supervisions. Probation officers thus shared the consequences of the decreased burden with social probation officers by using it in $30 \%$ to reduce their own supervisions and in $70 \%$ to reduce the number of supervisions social probation officers were entrusted with. The number of entrusted supervisions was 75,389 and came close to the number of own supervisions $(75,898)$, whereas it was 118,561 in the same period in 2014 . This means a decrease by 43,172 $(36.4 \%)$ in the number of entrusted supervisions. On average, one professional probation officer for adults had 24.8 entrusted supervisions in 2016, and 38.4 entrusted supervisions in the same period in 2014. The average burden with entrusted supervisions thus decreased by $13.8(35.9 \%)$ in two years. ${ }^{17}$

\section{Tasks of probation officers for adults}

The people who were submitted to the supervision of a court probation officer are individuals of legal age who were sentenced with: conditional discharge, conditional suspension of imprisonment not exceeding one year,

${ }^{17}$ Kuratorska Służba Sądowa w Polsce wg stanu na 31.12.2016 roku. Opracowanie Komisji p. 23. 
conditional early release, custodial sentence, electronic supervision, medicinal security measures. ${ }^{18}$ The supervision is supposed not to be experienced by the defendant as a nuisance, but as a measure serving them to help in the successful course of the trial period and give them protection over their lives. ${ }^{19}$ Thus, when supporting a defendant in the process of adapting them to active independent life and taking constructive social roles, ${ }^{20}$ a probation officer themselves plays different roles, i.e. of a supporter, mediator and counsellor.

The tasks carried out by professional probation officers in the penal department i.e. probation officers for adults are regulated by the Act of 6 June 1997 - Executive penal code (Journal of Law 2018, item 652). Article $173 \S 1$ of $\mathrm{kkw}$ states that "a professional probation officer organizes and conducts activities that are aimed at helping the condemned person socially readapt and preventing them from returning to crime, as well as consisting in controlling how the condemned person obeys the duties imposed on them by the court or linked to supervision".

A detailed list of a probation officer's duties is included in $\S 2$ of this article. Apart from supervising the condemned or perpetrator and controlling their duties in the trial period, the list also includes incidental proceedings, i.e. submitting motions to the court related to those under the probation officer's

${ }_{18}$ The lack of probation officers' specialization to work with those condemned who have special needs, such as those addicted to psychoactive substances, with mental disorders or sexual preference disorders, is a growing problem. B. Pastwa-Wojciechowska indicates difficulties related to diagnostic, legal and competence aspects in the context of the effectiveness of resocialization and therapeutic interactions with people who display specific behavioural symptoms and have personality disorderp. Probation officers themselves inform that they experience insufficient knowledge as far as pedagogical diagnosis is concerned. See: K. Nanowska, Kompetencje profesjonalne kuratorów sądowych dla dorostych w zmieniającej się rzeczywistości prawnej w perspektywie specjalizacji zawodowej, Edukacja Humanistyczna, 2016, 2, p. 139.

The difficulties in carrying out supervisions with security measures are also discussed in more depth by A. Kwieciński who underlines the need to have specialist trainings, prepare probation officers to work with disturbed individuals, and design a model of cooperation for probation officers and therapeutic and treatment facilities, as well as the need to ensure safety to probation officers (insurance, Police assistance). See: A. Kwieciński, Dozór kuratora sądowego nad sprawcami wymagającymi stosowania szczególnych środków leczniczych i terapeutycznych. Tymczasowy element zmian w prawie czy może ich nieunikniona perspektywa? Nowa Kodyfikacja Prawa Karnego, 2014, XXXIII, p. 197-214.

${ }_{19}$ W. Świda, Prawo karne, Warszawa 1989, p. 305. As pointed out by G. Wiciński, "supervision is characterized with educational objectives that result from trust the perpetrator was granted". Understanding supervision as an institution of penal and executive penal law, L. Bogunia also underlines its educational character especially in the aspect of providing assistance in the process of social readaptation without omitting the control function of supervision over those condemned. See more: G. Wiciński, Postępowanie incydentalne zwiazane z wykonywaniem kary pozbawienia wolności w programie probacji, Łódź 2012, p. 413 i n.; L. Bogunia, Dozór jako istotny element probacji, Nowa Kodyfikacja Prawa Karnego, 1999, IV, p. 235.

${ }^{20}$ The process of social readaptation was discussed by W. Ambrozik in: B. Urban, J. Stanik, Resocjalizacja, t. 2, Warszawa 2007, p. 182-183. 
custody, carrying out community interviews, providing post-penitentiary help, participating in court hearings, executing the imprisonment sentence, as well as activities related to preparing the condemned to the life following their release from the penitentiary unit. Activities linked to organizing and controlling penalty execution, penal measures and security measures in the system of electronic supervision also pertain to the professional probation officer (art. 173b § 1).

On the other hand, the scope of activities of the social probation officer are included in Article 174 of kkw.

It has to be noticed that the lawmaker made an attempt at categorizing the cases and people remaining under custody based on the risk of them reoffending. Three groups of risk were distinguished: 1) reduced-risk group (A), 2) basic group (B), 3) increased-risk group (C). The reduced-risk group (A) encompasses those who were adjudicated with conditional discharge and have no previous criminal record, and who are believed to obey the legal order in the trial period, in particular not commit a crime again. The increased-risk group (C) includes above all those condemned who committed a similar crime after being sentenced or in the trial period; addicted individuals who committed a crime due to their use of alcohol; those sentenced for crime against sexual liberty or decency on an underage person, as well as crime against sexual liberty of adults; convicted due to using violence in their families and who live with the victim; linked to criminal subcultures; supervised who require intense interactions in the trial period due to their previous criminal record or lifestyle. On the other hand, the basic-risk group (B) encompasses people who do not match the criteria for the reduced-risk or increased-risk groups. ${ }^{21}$ At this point it is impossible, however, to refer to the above regulations, because even though the lawmaker obliges probation officers to assign those under their custody to one of the three above-mentioned risk groups, they do not indicate any reliable tools to use in order to carry out this division.

${ }^{21}$ Previously, risk groups were described in the Order of 26 February 2013 on the methods of executing duties and rights by probation officers in executive penal cases that the entire probation service community greatly anticipated. Indeed, the order replied to the demands made by professional probation officers, among others: the time necessary for starting supervision and assigning it to a social probation officer and going through the documentation and making contact with the defendant were made more realistic, the activities taken up by probation officers during supervision, executing an imprisonment sentence and completing the so-called release programme were made more precise. However, the order is another legal act that assigns tasks to probation officers and expects even greater effectiveness of their activitiep. In this situation, it is difficult to talk about rationalizing the work of probation officers; instead one should talk about work burden. See: T. Jedynak, O diable, który tkwi w szczegótach http:/ / docplayer. pl/7989443-O-diable-ktory-tkwi-w-szczegolach.html [accessed on 20.04.2018].

The current regulations on risk groups are included in the Executive penal code, art. 169b 
In many countries linked to the Anglo-Saxon tradition of law and resocialization, the diagnostic process is described using the categories of assessment. What is diagnosed are risk factors understood as features linked to the perpetrator or situations that are linked to engaging in criminal activity as proved by research. Identifying the risk created by crime perpetrators and factors linked to them returning to criminal activity is crucial for selecting effective forms of resocializing intervention (...) At present, the direction of activities in this respect is set by the what-works approach and the theoretical R-N-R model linked to it, whose name stems from the key rules of effective resocializing intervention, i.e. the rules of risk, need and responsivity. ${ }^{22}$

In Poland, it is just the beginning, and yet, as suggested by Jana Chojecka, it is worth discovering the resocialization value of this model, working out diagnostic tools, and based on them making pedagogical interventions, rather than decide about the fate of perpetrators subjectively based on the knowledge and experience of probation officers themselves. ${ }^{23}$

When completing their statutory tasks and acting in line with legal regulations, in certain organizational structures, the probation officer, in accordance with the Code of ethics of the probation officer, ${ }^{24}$ is entitled to freely choose the methods and means of interaction that comply with the present state of knowledge in the fields of pedagogy, psychology, resocialization and social work. Autonomy/discretionary character are typical of legal professions, yet in the situation of work dependence in the hierarchical structure of the judiciary some activities of probation officers can be limited. Therefore, a probation officer should be fully convinced that the decisions they take are right; they are required to be decisive and sometimes even courageous. It is necessary for

22 A. Barczykowska, Zastosowanie modelu $R-N-R$ w diagnozie resocjalizacyjnej dorostych sprawców przestępstw - rozwiązania angielskie, Studia Edukacyjne, 2015, 34, p. 243-244.

${ }_{23}$ More: J. Chojecka, Model dla wszystkich?: spory wokół koncepcji szacowania ryzyka recydywy, Resocjalizacja Polska, 2014, 7, p. 97-99;

D. Wójcik notices that the topic of assessing the risk of reoffending has been developing in Polish criminological publications for several years now, yet there are only few authors who have touched upon the theoretical and practical assumptions of the what-works movement, R-N-R model or use of diagnostic tools in their scientific paperp. The list of authors includes, among others, Barbara Stańdo-Kawecka, Mariusz Sztuka, Józef Gierowski and Jana Chojecka. One can assume that it is just the beginning. In her paper, Wójcik presented detailed information about constructing, using and functioning of tools for assessing the risk of reoffending, the possibility of monitoring the transformation in perpetrators who were submitted to a penalty, penal measure or corrective intervention. The author gave a very precise summary of the criticism that the R-N-R model received, the methodological problems occurring in the process of building tools and the difficulties the people who use them come acrosp. These are incredibly valuable guidelines that those who want to deal with the issues of assessing the risk of reoffending among criminals should familiarize themselves with. See: D. Wójcik, Stosowanie w postepowaniu karnym narzędzi diagnostyczno-prognostycznych stużacych oszacowaniu ryzyka powrotności do przestepstwa, Warszawa 2012.

${ }^{24}$ Resolution of the State Council of Probation Officers (Krajowa Rada Kuratorów) of 6 May 2004, Code of ethics of probation officers (Kodeks etyki kuratora sądowego), art. 5. 
them to develop the need to be attentive, notice details and be sympathetic in order not to fall into a routine and treat different cases in a conventional way. The discretionary character of the probation officer profession means confidentiality, autonomy to make decisions, being able to freely recognize, assess and decide..$^{25}$

The actions described in the regulations should be tools that serve to achieve aims which are supported by the legal system, however:

- Tools are often imperfect, because procedures are only approximations of the methods of arriving at correct decisions, many of which refer to exceptional and unique circumstances;

- Procedures require their users to correct them and have an initiative in introducing changes in them;

- Being sensitive to the evil and harm and having a desire to improve someone else's fate sometimes requires courage, accepting additional responsibility, activity in a field that is wider than one's own work duties;

- Formalism sometimes serves as a cover for cowardice, dilatory tactics and blind obedience. ${ }^{26}$

The probation officer profession should thus be carried out by individuals who are open towards other people, reflective, think long-term and do not accept responsibility for others, but are responsible for their own actions towards the people their supervise. In this aspect, the ability to use the support and assistance of other specialists, services and institutions is indispensable ${ }^{27}$ in order to work out the best solutions possible. It is also necessary to strike the right balance between legal formalism and pedagogical vision of individual resocialization.

I shall not quote the definition of effectiveness of educational interventions taken up in the area of court probation, because it seems more accurate to refer to R. Opora's proposal which enumerates guidelines (rules) necessary for probation officers to work with individual cases. They are important because they are based on theoretical references linked to situations that probation officers experience in their practice. It is not a so-called list of wishful thinking referring to a probation officer's personality, but a comprehensive application of a probation officer's knowledge, skills and previous experience

${ }^{25}$ A. Janus-Dębska, Dylematy w pracy kuratora sądowego w świetle badań własnych, cz. I, Probacja, 2016, 3, p. 60-61.

${ }^{26}$ Ibidem.

${ }^{27}$ The cooperation of a probation officer with other services in the local environment was polemically discussed by Danuta Jurczyk and Andrzej Staniucha who indicated that there are various types of misunderstandings when interpreting the tasks and duties of probation officers that are a consequence of legal acts and that are carried out in practice. See: D. Jurczyk, A. Staniucha, Wspótpraca kuratorów sądowych z innymi stużbami w realizowaniu zadań profilaktyczno-resocjalizacyjnych, Resocjalizacja Polska, 2015, 10. 
in their work with the individuals they supervise. In reality, each probation officer works out their own catalogue of reactions, behaviours and interactions with the individuals they supervise and their families. The above-mentioned R. Opora states that the following strategies should contribute to a probation officer's effective prevention of reoffending by a perpetrator: using the social theory of learning and taking into account risk factors, using social support; taking into account risk factors and criminogenic needs evaluated with appropriately reliable methods in order to inform about the level of threat of reoffending; using multidimensional approaches referring to learning styles, motivation and talents; identifying the strengths of those under their custody; aftercare focused on preventing reoffending; clear rules and instructions directed at those under their custody; improving the competences of resocializing staff and maintaining appropriate interpersonal relations with each other; adapting the resocialization offer to the local context and specific characteristics of those under their custody. ${ }^{28}$

\section{Conclusions}

The court probation officer is undoubtedly an important instrument of social control and resocializing interaction in a free environment. It serves as a barometer, every now and then facing new challenges that are a consequence of social and economic transformations. In the ever-changing social reality, defendants' behaviour also undergoes modifications. This requires each probation officer to be attentive and flexible, and react to the resocializing needs of those under their custody.

The formal guidelines of the United Nations included in "the minimum rules for measures that are alternative to imprisonment" (Tokyo regulations) state that the objective of probation interactions is to provide the supervised individual with comprehensive psychological, material and social assistance, enhance their ties with the local community and reduce the probability of them reoffending. Yet, the reduction of the reoffending rate seems to be a priority and a socially expected task. As rightly observed by A. Węgliński,

${ }^{28}$ R. Opora, Refleksje na temat wspótczesnej resocjalizacji w kontekście jej efektywności, Resocjalizacja Polska, 2010,1, p. 213. The effectiveness of the sanctions adjudicated can be evaluated by comparing the behaviour before and after the sanction and the resocializing intervention linked to it, but it is imprecise for several reasonp. First of all, it assumes that one's behaviour was not influenced by anything else than the sanction adjudicated. Secondly, this plan assumes that in case the given sanction is not applied, the perpetrator will maintain the same level of antisocial behaviourp. Thirdly, reoffending should not be measured only by the direct rate of reoffense, because each direct measure rate is usually distorted to some extent. More: R. Opora, Kierunki wspótczesnych badań nad efektywnością oddziaływań resocjalizacyjnych, Probacja, 2012, III, p. 67-68. 
the role of a court probation officer cannot be reduced to carrying out prevention and control actions which come down to informing the court about which of the supervised individuals is most likely to reoffend. It misrepresents the idea of probation service and does not allow to manage each case holistically. ${ }^{29}$ The situation is further aggravated by extending the list of tasks for professional court probation officers in the name of professionalizing probation and improving work effectiveness..$^{30} \mathrm{It}$ is worth adding that it imposes additional duties related to their direct educational work with defendants, for example by equipping probation officers with breathalysers and sets that make it possible to detect the use of psychoactive substances by the supervised individuals (previously, these were the duties of the police). It also includes duties that are not linked to resocialization, but to organizational and administrative work.

Thus, if the judicature practice is to increase the number of non-custodial sentences and therefore require probation officers to effectively complete probation tasks and educational activity, it is necessary to equip probation officers with even greater normative trust, and at the same time provide them with specialist support coming from other services and institutions.

\section{BIBLIOGRAPHY}

90 lat kurateli sądowej w Polsce, Historia - Teraźniejszość - Przyszłość, Warszawa 2010.

Barczykowska A., Zastosowanie modelu $R-N-R$ w diagnozie resocjalizacyjnej dorostych sprawców przestępstw - rozwiazania angielskie, Studia Edukacyjne, 2015, 34.

Bogunia L., Dozór jako istotny element probacji, Nowa Kodyfikacja Prawa Karnego, 1999, IV.

Brudnoch A. (cooperation: B. Grabowska-Moroz), Status zawodowych kuratorów sądowych w polskim wymiarze sprawiedliwości, Analizy i Rekomendacje, 2016, 3, Helsińska Fundacja Praw Człowieka.

Chojecka J., Model dla wszystkich?: spory wokót koncepcji szacowania ryzyka recydywy, Resocjalizacja Polska, 2014, 7.

Ereciński T., Gudowski J., Iwulski J., Komentarz do prawa o ustroju sadów powszechnych i ustawy o Krajowej Radzie Sąownictwa, Warszawa 2002.

${ }^{29}$ A. Węgliński, Autopercepcja bezpośrednich oddziatywań wychowawczych społecznych kuratorów sądowych, Lubelski Rocznik Pedagogiczny, 2016, XXXV, 2, p. 76-77.

${ }^{30}$ In the opinion of the Ministry of Justice, assigning difficult cases to professional probation officers is supposed to contribute to increased work effectiveness of probation officers and reduced number of imprisonment sentencep. Yet, in the same study that the Ministry of Justice refers to, IWS proved that: "there is no clear link between which probation officer carried out supervision and what its effectiveness wap. On the other hand, attempts were made to clarify why so many supervisions carried out by professional probation officers were characterized with the supervised individuals' reoffending. This can be explained by the fact that probation officers are burdened with a much larger number of own supervisions than social probation officers, and may thus have less time to work with each supervised individual", T. Jedynak, O diable, który tkwi w szczegótach; http:/ / kurator.webd.pl/pdf [accessed on 02.05.2018]. 
Gromek K., Kuratorzy sądowi. Komentarz do ustawy z 27 lipca 2001, Warszawa 2002.

Janus-Dębska A., Dylematy w pracy kuratora sądowego w świetle badań własnych, cz. I, Probacja, 2016, 3.

Jedynak T., O diable, który tkwi w szczegótach; http:/ / kurator.webd.pl/pdf

Jurczyk D., Staniucha A., Wspótpraca kuratorów sądowych z innymi stużbami w realizowaniu zadań profilaktyczno-resocjalizacyjnych, Resocjalizacja Polska, 2015, 10.

Kuratorska Służba Sądowa w Polsce wg stanu na 31.12.2016 roku. Opracowanie Komisji ds Monitorowania Warunków Pracy, Płac i Obciążeń Obowiązkami Kuratorów Krajowej Rady Kuratorów Sądowych, Warszawa 2017.

Kwieciński A., Dozór kuratora sadowego nad sprawcami wymagającymi stosowania szczególnych środków leczniczych i terapeutycznych. Tymczasowy element zmian w prawie czy może ich nieunikniona perspektywa? Nowa Kodyfikacja Prawa Karnego, 2014, XXXIII.

Nanowska K., Kompetencje profesjonalne kuratorów sądowych dla dorostych w zmieniajacej się rzeczywistości prawnej w perspektywie specjalizacji zawodowej, Edukacja Humanistyczna, 2016, 2.

Nanowska K. (book review) Ł. Wirkus, Stres w pracy kuratora sądowego. Studium teoretyczno - empiryczne, Edukacja Humanistyczna, 2016, 2.

Opora R., Kierunki wspótczesnych badań nad efektywnością oddziaływań resocjalizacyjnych, Probacja, 2012, III.

Opora R., Refleksje na temat wspótczesnej resocjalizacji w kontekście jej efektywności, Resocjalizacja Polska, 2010, 1.

Rozporządzenie Ministra Sprawiedliwości z 9 czerwca 2003 r. w sprawie standardów obciążenia pracą kuratora zawodowego (DzU 2003, nr 116, poz. 1100).

Skowroński B., Stres sądowych kuratorów zawodowych wykonujacych orzeczenia w sprawach karnych i nieletnich, Resocjalizacja Polska, 2015, 10.

Świda W., Prawo karne, Warszawa 1989.

Urban B., Stanik J., Resocjalizacja, tom 2, Warszawa 2007.

Ustawa z 27 lipca 2001 r. o kuratorach sądowych (DzU 2014, poz. 795), w skrócie u.o.k.s., art. 3 ust. 1.

Węgliński A., Autopercepcja bezpośrednich oddziaływań wychowawczych społecznych kuratorów sadowych, Lubelski Rocznik Pedagogiczny, 2016, XXXV, 2.

Wiciński G., Postępowanie incydentalne zwiazane z wykonywaniem kary pozbawienia wolności w programie probacji, Łódź 2012.

Wójcik D., Stosowanie w postępowaniu karnym narzędzi diagnostyczno-prognostycznych stużących oszacowaniu ryzyka powrotności do przestepstwa, Instytut Wymiaru Sprawiedliwości, Warszawa 2012. 